\title{
COMPARISON OF ORAL HEALTH STATUS AMONG NORMAL AND DISABLED CHILDREN OF KARACHI, PAKISTAN.
}

1. BDS, MPH

Associate Professor \& Head Department of Preventive \& Community Dentistry

Sindh Institute of Oral Health Sciences

Jinnah Sindh Medical University.

2. BDS, MSc

Assistant Professor

Department of Prosthodontics

Fatima Jinnah Dental College.

3. BDS, MSc

Assistant Professor and Head of Department

Department of Science of Denta Materials, Baharia Medical and Dental College, Baharia University.

4. MSc (Statistics), BS (Hon.) Statistics

Senior Statistician

Department of Research Evaluation Unit

College of Physicians \& Surgeons Pakistan.

Correspondence Address:

Khadijah Abid

CPSP, 7th central street, DHA phase 2 ,

Karachi, Pakistan

khadijahabid@gmail.com

Article received on:

$13 / 08 / 2018$

Accepted for publication:

04/01/2019

\section{INTRODUCTION}

Oral health has strong psychological, biological and social projections, because it affects communication and aesthetics, and the quality of life is affiliated with oral health status. ${ }^{1}$ Oral health of disabled children is noted to be the most common issue \& unmet need. Disabled children are at greater risk of poorer oral health due to other major disease such as frequent oral infections, moderate to severe malocclusion, periodontal disease \& craniofacial birth defects. ${ }^{2}$ The oral needs among them may be compromised due to limited access to facilities of oral health care, neglection of parents or care takers, socioeconomic status or communication barriers. ${ }^{3}$ Therefore, the disabled children appear to have more worsen oral health as compared to normal population. ${ }^{4}$

\begin{abstract}
Marium Azfar' ${ }^{1}$, Sameer Quraeshi² ${ }^{2}$, Syed Ahmed Omer ${ }^{3}$, Khadijah Abid ${ }^{4}$
ABSTRACT... Objectives: To compare the oral hygiene status of normal children with hearing Pakistan. Period: 6 months from October 2017 to April 2018. Material and Methods: A total of 210 children of age 7-15 years of either gender were enrolled in the study; 70 hearing \& 列 data was analyzed using SPSS version 23. Results: Out of 70 hearing and speech impaired children, majority had fair hygiene status $(41.4 \%), 38.6 \%$ had good hygiene status and only and was observed among children with hearing and speech impairment and Down syndrome as compared to normal children. Hence, there is a high need for an epidemiological survey should be made to spread the awareness and importance of oral health among these children and their family because everyone deserves the opportunity of good oral health and hygiene.
\end{abstract}

Deaf, Down Syndrome, Hearing and Speech Impaired Children, Normal Population, Oral Health, Oral Hygiene Status. among normal and disabled children of Karachi, Pakistan. Professional Med J 2019; 26(11):2009-2014. DOI: 10.29309/TPMJ/2019.26.11.4230

Hearing and speech impairment is the common disability in childhood. Almost two to three children per 1000 have some level of permanent congenital hearing loss. ${ }^{5}$ According to WHO estimate there are 360 million people globally with hearing impaired, among them $9 \%$ of these are children under the age of $15 .{ }^{6}$ Whereas, Down syndrome is a congenital autosomal anomaly caused due to the changes in the sequence of DNA of chromosome 21. According to WHO the global incidence of Down syndrome (DS) is estimated as 1 out of $600-1000$ live births. ${ }^{7,8}$ Children with such disabilities has the greatest barrier of communication and understanding. They cannot understand or cooperate with dental healthcare providers easily.

Hence, there is no current data available on the 
oral status of children with hearing and speech impairment \& Down syndrome in comparison with normal children of Karachi, Pakistan. Therefore, the present study was designed to provide primary data for development and planning of regional or national oral health programs for these children.

\section{METHODOLOGY}

It was a cross-sectional study conducted at the Special needs children school, Deaf Reach School \& a public school of Karachi, Pakistan and duration of study was 6 months. A total of 210 children of age 5-15 years of either gender were enrolled in the study; 70 hearing \& speech impaired children, 70 Down syndrome children and 70 normal children were randomly selected for comparison. Participants exhibiting other forms of systematic diseases, compound disability or extremely uncooperative individuals were excluded from the study.

Informed consent was taken from school admin and parents of the children to participate in the study. The clinical examination was carried according to World Health Organization (WHO) techniques ${ }^{9}$ in the OPD of Integrated Occupational Health Services (IOHS) by the examiner. The demographic information such age, gender, weight \& height of the children was recorded. Other related information regarding previous dental visits, frequency of tooth brushing \& material used for brushing were obtained under the supervision of school interpreters.

The children were then examined for oral status by making them sit on the upright chair in adequate light using autoclaved instruments. Each surface of mouth was checked by using plain mouth mirror and WHO probe. Caps, gloves, masks and gauze were used in accordance with infection control guidelines. Oral hygiene was evaluated by using the simplified oral hygiene index (OHI-S) introduced by Green and Vermillion. ${ }^{10}$ OIH-S score was labelled for oral cleanliness as "good" for score between 0.11.2, "fair" between 1.3-3.0 and "poor" between 3.1-6.0. ${ }^{11}$

Data analysis was carried out using the SPSS
Version 23. Frequencies and percentages was calculated for all the qualitative variables. Mean \& SD was calculated for all the quantitative variables.

\section{RESULTS}

The study sample was consisted of 210 children with mean age as $12.43 \pm 4.21$ years. Out of 210 , 134 were males and 76 were females. Majority of the children had never visited the dentist (54.8\%). About $61 \%$ of them brushed once daily, $26.7 \%$ of them brushed twice a day, $8.1 \%$ of them brushed after every meal and only $4.3 \%$ of them brushed less than one time. Majority of the subjects (91\%) were using toothpaste to clean their teeth, tooth power was used by $5.2 \%$ \& no material was used by $3.8 \%$ of the children. Among 70 children with hearing and speech impairment, the mean age was reported as $11.79 \pm 2.59$ years. Out of 70 , 47 were males and 23 were females. Majority of the children had never visited the dentist (57.1\%). About $54.3 \%$ of them brushed once daily, $31.4 \%$ of them brushed twice a day, $8.6 \%$ of them brushed after every meal and only $5.7 \%$ of them brushed less than one time. Majority of the subjects $(88.6 \%)$ were using toothpaste to clean their teeth, tooth power was used by $7.1 \%$ \& no material was used by $4.3 \%$ of the children. Among 70 children with Down syndrome, the mean age was reported as $14.20 \pm 5.91$ years. Out of 70 , 45 were males and 25 were females. Majority of the children had never visited the dentist (51.4\%). About $52.9 \%$ of them brushed once daily, $31.4 \%$ of them brushed twice a day, $8.6 \%$ of them brushed after every meal and only $7.1 \%$ of them brushed less than one time. Majority of the subjects (90\%) were using toothpaste to clean their teeth, tooth power was used by $5.7 \%$ \& no material was used by $4.3 \%$ of the children. Among 70 normal children, the mean age was reported as $14.0 \pm 1.30$ years. Out of 70,42 were males and 28 were females. Majority of the children had never visited the dentist (55.7\%). About $75.7 \%$ of them brushed once daily, $17.1 \%$ of them brushed twice a day and $7.1 \%$ of them brushed after every meal. Majority of the subjects $(94.3 \%)$ were using toothpaste to clean their teeth, tooth power was used by $2.9 \%$ \& no material was used by $2.9 \%$ of the children. (Table-l) 
Out of 70 hearing and speech impaired children, majority had fair hygiene status (41.4\%), 38.6\% had good hygiene status and only $20 \%$ had poor hygiene status. Out of 70 Down syndrome children, majority had good hygiene status $(45.7 \%), 28.6 \%$ had fair hygiene status and only $25.7 \%$ had poor hygiene status. Out of 70 normal children, majority had good hygiene status $(68.6 \%), 20 \%$ had fair hygiene status and only $11.4 \%$ had poor hygiene status. (Figure-1)

The age, gender, dental visits, frequency of brushing and material used wise distribution of oral hygiene status has been shown in Table-II.

\begin{tabular}{|l|c|c|c|c|}
\hline \multicolumn{1}{|c|}{ Variables } & Overall & $\begin{array}{c}\text { Children with hearing \& } \\
\text { speech impairment }\end{array}$ & $\begin{array}{c}\text { Down Syndrome } \\
\text { Children }\end{array}$ & Normal Children \\
\hline Age in years & $12.43 \pm 4.21$ & $11.79 \pm 2.59$ & $14.20 \pm 5.91$ & $14 \pm 1.30$ \\
\hline Gender & $134(63.8 \%)$ & $47(67.1 \%)$ & $45(64.3 \%)$ & $42(60 \%)$ \\
\hline $\begin{array}{l}\text { Male (\%) } \\
\text { Female (\%) }\end{array}$ & $76(36.2 \%)$ & $23(32.9 \%)$ & $25(35.7 \%)$ & $28(40 \%)$ \\
\hline $\begin{array}{l}\text { Dental Visits } \\
\text { Haven't visit (\%) }\end{array}$ & $115(54.8 \%)$ & $40(57.1 \%)$ & $36(51.4 \%)$ & $39(55.7 \%)$ \\
Visited at least once (\%) & $95(45.2 \%)$ & $30(42.9 \%)$ & $34(48.6 \%)$ & $31(44.3 \%)$ \\
\hline Brushing Frequency & $128(61 \%)$ & $38(54.3 \%)$ & $37(52.9 \%)$ & $53(75.7 \%)$ \\
Once a day (\%) & $56(26.7 \%)$ & $22(31.4 \%)$ & $22(31.4 \%)$ & $12(17.1 \%)$ \\
Twice a day (\%) & $17(8.1 \%)$ & $6(8.6 \%)$ & $6(8.6 \%)$ & $5(7.1 \%)$ \\
After every meal (\%) & $4(5.7 \%)$ & $5(7.1 \%)$ & 0 \\
\hline Less than once a day (\%) & $9(4.3 \%)$ & $62(88.6 \%)$ & $63(90 \%)$ & $66(94.3 \%)$ \\
\hline Material Used for Brushing & & $5(7.1 \%)$ & $4(5.7 \%)$ & $2(2.9 \%)$ \\
\hline Toothpaste & $191(91 \%)$ & $3(4.3 \%)$ & $3(4.3 \%)$ & $2(2.9 \%)$ \\
\hline $\begin{array}{l}\text { Tooth powder } \\
\text { No material }\end{array}$ & $11(5.2 \%)$ & $8(3.8 \%)$ & &
\end{tabular}

Table-I. Baseline characteristics of study variables

\begin{tabular}{|c|c|c|c|c|c|c|c|c|c|}
\hline \multirow{2}{*}{ Variables } & \multicolumn{3}{|c|}{$\begin{array}{l}\text { Hearing \& speech impaired } \\
\text { children }\end{array}$} & \multicolumn{3}{|c|}{ Down Syndrome Children } & \multicolumn{3}{|c|}{ Normal Children } \\
\hline & Good & Fair & Poor & Good & Fair & Poor & Good & Fair & Poor \\
\hline \multicolumn{10}{|l|}{ Age groups } \\
\hline $5-10$ years & $8(40)$ & 7(35) & $5(25)$ & $9(50)$ & 1(5.6) & $8(44.4)$ & 12(52.2) & $6(26.1)$ & $5(21.7)$ \\
\hline $11-15$ years & 19(38) & $22(44)$ & $9(18)$ & $23(44.2)$ & $19(36.5)$ & 10(19.2) & $36(76.6)$ & $8(17)$ & $3(6.4)$ \\
\hline \multicolumn{10}{|l|}{ Gender } \\
\hline Male (\%) & 18(38.3) & $19(40.4)$ & $10(21.3)$ & $20(44.4)$ & $11(24.4)$ & $14(31.1)$ & 26(61.9) & $11(26.2)$ & $5(11.9)$ \\
\hline Female (\%) & $9(39.1)$ & $10(43.5)$ & $4(17.4)$ & $12(48)$ & $9(36)$ & $4(16)$ & $22(78.6)$ & $3(10.7)$ & $3(10.7)$ \\
\hline \multicolumn{10}{|l|}{ Dental Visits } \\
\hline Haven't visit (\%) & $12(30)$ & $19(47.5)$ & $9(22.5)$ & $19(52.8)$ & $9(25)$ & $8(22.2)$ & $29(74.4)$ & $4(10.3)$ & $6(15.4)$ \\
\hline $\begin{array}{l}\text { Visited at least once } \\
(\%)\end{array}$ & $15(50)$ & 10(33.3) & $5(16.7)$ & 13(38.2) & $11(32.4)$ & $10(29.4)$ & $19(61.3)$ & $10(32.3)$ & $2(6.5)$ \\
\hline \multicolumn{10}{|l|}{ Brushing Frequency } \\
\hline Once a day (\%) & $16(42.1)$ & $15(39.5)$ & $7(18.4)$ & $19(51.4)$ & $12(32.4)$ & $6(16.2)$ & $38(71.1)$ & $9(17)$ & $6(11.3)$ \\
\hline Twice a day (\%) & $8(36.4)$ & $11(50)$ & $3(13.6)$ & $9(40.9)$ & $6(27.3)$ & $7(31.8)$ & $7(58.3)$ & $4(33.3)$ & $1(8.3)$ \\
\hline After every meal (\%) & $1(16.7)$ & 2(33.3) & $3(50)$ & $1(16.7)$ & $2(33.3)$ & $3(50)$ & $3(60)$ & $1(20)$ & $1(20)$ \\
\hline $\begin{array}{l}\text { Less than once a } \\
\text { day }(\%)\end{array}$ & $2(50)$ & $1(25)$ & $1(25)$ & $3(60)$ & $0(0)$ & $2(40)$ & 0 & 0 & 0 \\
\hline \multicolumn{10}{|c|}{ Material Used for Brushing } \\
\hline Toothpaste & 26(41.9) & $25(40.3)$ & $11(17.7)$ & $28(44.4)$ & $19(30.2)$ & $16(25.4)$ & $46(69.7)$ & 13(19.7) & $7(10.6)$ \\
\hline Tooth powder & $1(20)$ & $3(60)$ & $1(20)$ & $3(75)$ & $0(0)$ & $1(25)$ & $1(50)$ & $0(0)$ & $1(50)$ \\
\hline No material & $0(0)$ & $1(33.3)$ & $2(66.7)$ & $1(33.3)$ & 1(33.3) & $1(33.3)$ & $1(50)$ & $1(50)$ & $0(0)$ \\
\hline \multicolumn{10}{|c|}{ Table-II. Distribution of variables between groups } \\
\hline
\end{tabular}




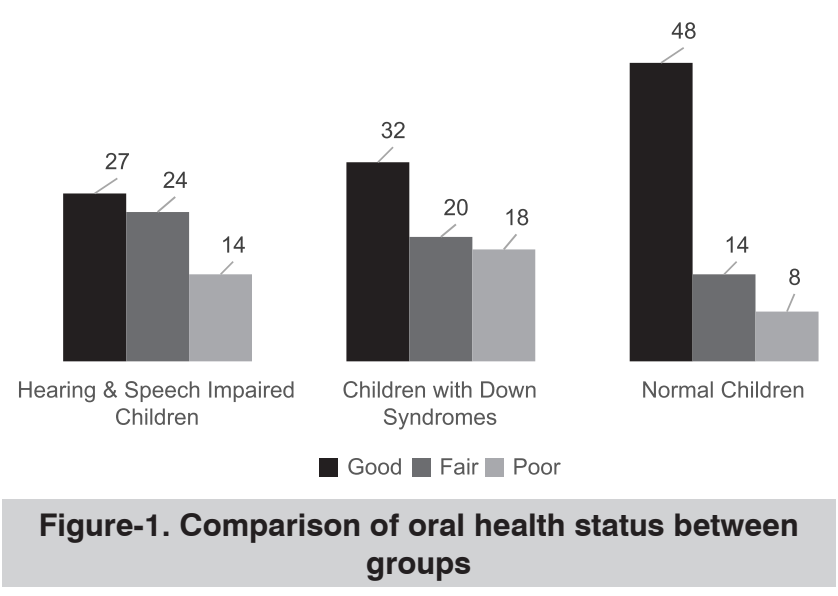

\section{DISCUSSION}

The disabled children experiences high levels of dental disease as compared to normal population because it is difficult for them to access oral health care. In the current study, majority of the disabled children had never went for dental checkups. The similar proportions was presented in previous literature of the disabled children. ${ }^{4,12,13}$ In the present study of proportion of haven't visited to dentist is high for normal population as well. "The reasons for not seeking dental services are individuals themselves (such as the lack of perceived need, anxiety or fear, financial considerations, and lack of access), dental profession (inappropriate manpower resources, uneven geographical distribution, training inappropriate to changing needs and demands, and insufficient sensitivity to patient's attitudes and needs) and society (insufficient public support of attitudes conducive to health, inadequate oral health care facilities, inadequate oral health manpower planning, and insufficient support for research). ${ }^{14}$

In our study, low proportion has been seen among disabled and normal children for didn't brush their teeth whereas majority of the children brushed their teeth once daily $(61 \%), 26.7 \%$ of the children brushed twice a day and $8.1 \%$ of the children rinsed their mouth after every meal. Majority of the children used toothpaste \& tooth brush as cleaning material. The similar findings was observed in study by Prashanth ST et al. at Banglore among disabled children. About $62.35 \%$ children brushed their teeth only once in the morning \& $37.65 \%$ children responded that they brushed twice a daily \& $98.82 \%$ of children clean their teeth with toothbrush. ${ }^{15}$ "In the study by Bhambere SD for visual impaired children found $29.41 \%$ of the children brushed their teeth twice a day and about $64.7 \%$ children brushed only one time in morning. About $98.82 \%$ responded that they used tooth brush to clean their teeth whereas only 9 children used finger to clean their teeth. The frequency using tooth paste along with cleaning tool was observed as $100 \% .^{16}$

In the present study, most of the disabled children had fair \& good hygiene status, however the proportion of good oral hygiene was observed high among normal children. In the study by Sinha $\mathrm{N}$ et al. found higher poor oral hygiene among disabled children as compared to controls. Another study by Shaw et al reported that there was a greater prevalence of dental caries and poorer oral hygiene in handicapped children attending special schools. ${ }^{17}$ Data from a study of 12-year-old disabled children in Flanders (Belgium) showed poor oral hygiene in 31.8\% of children, with no significant differences found among disability types. ${ }^{18}$ A study of oral hygiene among mentally retarded female children in Riyadh also showed very poor oral hygiene. ${ }^{19}$ Several other studies have also found poor results for periodontal health and oral cleanliness among children with disabilities. ${ }^{18,20,21}$ These results may be due to low physical abilities, which could cause difficulties in tooth brushing among disabled children.

In the present study, with increase in age of the disabled and normal children the good hygiene practice has also increased. However the frequency of good hygiene status was high among males as compared to females. Good \& fair oral status are prevalent among disabled and normal children who brushed their teeth at least one time daily. The most frequent material used for practicing good oral hygiene is tooth paste by all the children.

\section{CONCLUSION}

The high proportion of poor oral health was observed among children with hearing and 
speech impairment and Down syndrome as compared to normal children. Hence, there is a high need for an epidemiological survey followed by the comprehensive dental care programs for disabled children as well as efforts should be made to spread the awareness and importance of oral health among these children and their family because everyone deserves the opportunity of good oral health and hygiene."

Copyright@ 04 Jan, 2019.

\section{REFERENCES}

1. Gift HC, Atchison KA. Oral health, health, and healthrelated quality of life. Med Care. 1995:NS57-77.

2. Rocha LL, de Lima Saintrain MV, Vieira-Meyer APGF. Access to dental public services by disabled persons. BMC Oral Health. 2015; 15(1):35.

3. Nahar SG, Hossain MA, Howlader MBU, Ahmed A. Oral health status of disabled children. Bangladesh Med Res Counc Bull. 2010; 36(2):61-3.

4. Suma G, Das UM, Akshatha B. Dentition status and oral health practice among hearing and speechimpaired children: A cross-sectional study. Int J Clin Pediatr Dent. 2011; 4(2):105.

5. Chadha NK, Chadha R, James AL. Why are children deaf? Paediatr Child Health. 2009; 19(10):441-6.

6. Elahi MM, Elahi F, Elahi A, Elahi SB. Paediatric hearing loss in rural Pakistan. J Otolaryngol Head Neck Surg. 1998; $27(6): 348$.

7. Asokan S, Muthu M, Sivakumar N. Dental caries prevalence and treatment needs of down syndrome children in Chennai, India. Indian J Dent Res. 2008; 19(3):224.

8. Swisher T, Pryor H, Schurman D. At higher risk for oral disease, patients with Down syndrome require specialized oral care instruction. 2017.

9. WHO. Oral health surveys: Basic methods: World Health Organization; 2013.

10. Greene JG, Vermillion JR. The simplified oral hygiene index. J Am Dent Assoc. 1964; 68(1):7-13.
11. Al-Mutawa S, Shyama M, Al-Duwairi Y, Soparkar P. Oral hygiene status of Kuwaiti schoolchildren/Etat d'hygiene bucco-dentaire des ecoliers koweitiens. East Mediterr Health J. 2011; 17(5):387.

12. Oredugba FA. Use of oral health care services and oral findings in children with special needs in Lagos, Nigeria. Spec Care Dentist 2006; 26(2):59-65.

13. Kumar S, Dagli RJ, Mathur A, Jain M, Duraiswamy $\mathrm{P}$, Kulkarni $\mathrm{S}$. Oral hygiene status in relation to sociodemographic factors of children and adults who are hearing impaired, attending a special school. Spec Care Dentist. 2008; 28(6):258-64.

14. Cohen LK. Converting unmet need for care to effective demand. Int Dent J. 1987; 37(2):114-6.

15. Prashanth S, Bhatnagar S, Das UM, Gopu H. Oral health knowledge, practice, oral hygiene status, and dental caries prevalence among visually impaired children in Bangalore. J Indian Soc Pedod Prev Dent. 2011; 29(2):102.

16. Bhambere SD. Oral health status, knowledge and caries occurrence in visually impaired students. $J$ Indian Soc Pedod Prev Dent. 2011 Jan-Mar; 29(1):25-7

17. Reddy K, Sharma A. Prevalence of oral health status in visually impaired children. J Indian Soc Pedod Prev Dent. 2011; 29(1):25.

18. Gizani S, Declerck D, Vinckier F, Martens L, Marks L, Coffin G. Oral health condition of $12 \square$ year $\square$ old handicapped children in Flanders (Belgium). Community Dent Oral Epidemiol. 1997; 25(5):352-7.

19. Al-Qahtani C, Wyne A. Caries experience and oral hygiene status of blind, deaf and mentally retarded female children in Riyadh, Saudi Arabia. Odontostomatol Trop. 2004:37-40.

20. Broers D, Resida G. Post-academic specialties 9. Dental care of disabled children living at home. Ned Tijdschr Tandheelkd. 2007; 114(3):129-33.

21. Martens L, Marks L, Goffin G, Gizani S, Vinckier F, Declerck $D$. Oral hygiene in $12 \square$ year $\square$ old disabled children in Flanders, Belgium, related to manual dexterity. Community Dent Oral Epidemio. 2000; 28(1):73-80. 


\begin{tabular}{|c|l|l|}
\hline \multicolumn{3}{|c|}{ AUTHORSHIP AND CONTRIBUTION DECLARATION } \\
\hline Sr. \# & \multicolumn{1}{|c|}{ Author(s) Full Name } & \multicolumn{1}{c|}{ Contribution to the paper } \\
\hline 1 & Marium Azfar & $\begin{array}{l}\text { Conception \& Study design, } \\
\text { Developed the methodology. } \\
\text { Data collection, Literature } \\
\text { search. } \\
\text { Review it critically for important } \\
\text { intellectual content. } \\
\text { Analysis is interpretation of } \\
\text { data, wrote the manuscript \& } \\
\text { made the finalchanges. }\end{array}$ \\
\hline 3 & Sameer Quraeshi & Syed Ahmed Omer \\
\hline 4 & Khadijah Abid & \\
\hline
\end{tabular}

